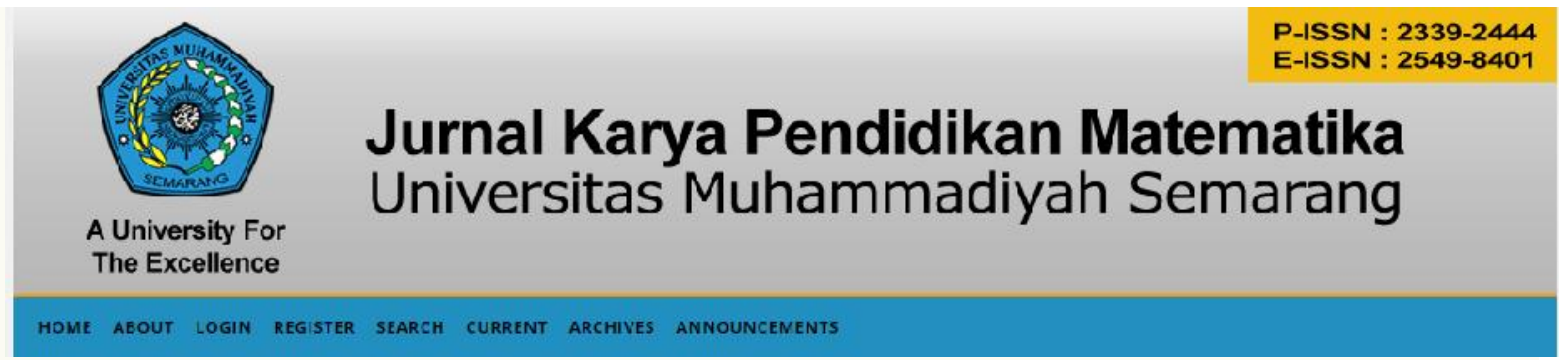

\title{
PERBEDAAN HASIL BELAJAR MATEMATIKA DARI PENERAPAN JIGSAW DAN TSTS PADA SISWA KELAS XI SMAN 1 AMBARAWA
}

\author{
Dinda Ayu Septiana ${ }^{1}$, Erlina Prihatnani ${ }^{2}$ \\ Pendidikan Matematika FKIP Universitas Kristen Satya Wacana \\ ${ }^{1}$ Mahasiswa Pendidikan Matematika FKIP UKSW, email: 202015014@student.uksw.edu \\ ${ }^{2}$ Dosen Pendidikan Matematika FKIP UKSW, e-mail: erlinaprihatnani@gmail.com
}

\begin{tabular}{ll}
\hline \multicolumn{2}{l}{ Article history } \\
\hline Submission & $:$ 22/09/2018 \\
Revised & $:$ \\
Accepted & $: 11 / 10 / 2018$
\end{tabular}

Keyword:

jigsaw, tsts (two stay two stray), learning results, algebraic function derivatives

\begin{abstract}
The 2013 curriculum requires students to learn from anyone including their peers. There are several learning models that emphasize this, including Jigsaw and TSTS (Two Stay Two Stray). This study aims to compare learning results from the application of the two models to students of class XI of SMAN 1 Ambarawa. Sampling with cluster random sampling resulted in a sample of students of class XI MIPA 1 as an experimental class and students of class XI MIPA 2 as a comparison class. A quasi-experimental study with the design of The Randomized Control Group Pretest-Posttest Design was carried out on mathematics learning on the material derivative from algebraic functions. Test different mean initial ability of students by using the Mann-Whitney test produces a significant value of 0.443 (more than 0.05), meaning that the initial conditions of both classes are balanced. The hypothesis test with the Mann-Whitney test produced a significant amount of 0.029 (less than 0.05), with the average in the experimental class (76.81) higher, than the comparison class average (73.79). Therefore, it can be concluded that the application of jigsaw produces the results of mathematics learning in class XI students of SMAN 1 Ambarawa better than the application of TSTS
\end{abstract}

\section{Pendahuluan}

Kurikulum 2013 merupakan tindak lanjut dari kurikulum berbasis kompetensi (KBK) yang diujicoba pada tahun 2004 (Mulyasa, 2013:66). Pengembangan Kurikulum 2013 bertujuan dalam rangka mewujudkan tujuan pendidikan nasional, yakni: "Berkembangnya potensi peserta didik agar menjadi manusia yang beriman dan bertakwa kepada Tuhan Yang Maha Esa, berakhlak mulia, sehat, berilmu, cakap, kreatif, mandiri, dan menjadi 
warga negara yang demokratis serta bertanggungjawab" (Pasal 3 Undang-Undang No. 20 tahun 2003). Prinsip Kurikulum 2013 adalah pembelajaran yang berpusat pada peserta didik, dimana peserta didik harus aktif dalam proses pembelajaran dan bukan guru yang mendominasi. Selain itu salah satu prinsip Kurikulum 2013 adalah belajar dari berbagai sumber, hal ini berarti siapa pun bisa dijadikan sumber belajar termasuk teman sebaya. Model pembelajaran yang menuntut siswa untuk aktif dalam proses pembelajaran, salah satunya adalah model pembelajaran kooperatif (cooperative learning).

Pembelajaran kooperatif mengacu pada metode pembelajaran dimana peserta didik bekerja sama dalam kelompok kecil dan saling membantu dalam belajar (Huda, 2011:32). Menurut Nurulhayati (Rusman, 2013:204), terdapat lima unsur dasar cooperative learning, yaitu 1) ketergatungan yang positif, 2) pertanggung jawaban individual, 3) kemampuan bersosialisasi, 4) tatap muka, 5) evaluasi proses kelompok. Kerja sama antar anggota kelompok sangat dibutuhkan untuk mencapai tujuan, tapi ada tanggung jawab pribadi mengenai materi pelajaran dalam anggota kelompok sehingga siswa termotivasi untuk membantu temannya. Pembelajaran kooperatif merupakan metode pembelajaran yang dikenal sejak lama dalam dunia pendidikan, dimana guru mendorong para siswa untuk bekerjasama dalam tugas-tugas tententu. Siswa diharapkan dapat saling membantu, saling mendiskusikan dan berargumentasi untuk mengasah pengetahuan yang mereka kuasai (Slavin, 2005:4). Model pembelajaran kooperatif yang memfasilitasi siswa untuk dapat aktif belajar dari teman-temannya diantaranya adalah model pembelajaran Jigsaw dan TSTS (Two Stay Two Stray).

Teknik belajar mengajar Jigsaw pertama kali dikembangkan oleh Aronson sebagai metode belajar kooperatif (Lie, 2002:69). Menurut Lie (Rochman dan Majid, 2014:221), pembelajaran kooperatif model Jigsaw merupakan model belajar kooperatif dengan cara siswa belajar dalam kelompok kecil yang terdiri atas empat sampai enam orang secara heterogen, dan siswa bekerjasama saling ketergantungan positif dan bertanggung jawab secara mandiri. Menurut Rusman (2013:218), karakteristik model pembelajaran kooperatif Jigsaw yaitu anggota kelompok bertanggung jawab terhadap keberhasilan kelompoknya dan ketuntasan bagian materi yang dipelajari. Langkah-langkah model pembelajaran tipe Jigsaw adalah 1) siswa dikelompokkan dengan anggota \pm 4 orang, 2) tiap orang dalam tim diberi materi dan tugas yang berbeda, 3) anggota dari tim yang berbeda dengan penugasan yang sama membentuk kelompok baru (kelompok ahli), 4) setelah kelompok ahli berdiskusi, tiap anggota kembali ke kelompok asal dan menjelaskan kepada anggota kelompok tentang subbab yang mereka kuasai, 5) tiap tim ahli mempresentasikan hasil diskusi, 6) pembahasan, 7) penutup.

Menurut Ibrahim, dkk (Rochman dan Majid, 2014: 222), kooperatif tipe jigsaw memiliki kelebihan yaitu 1) dapat memberikan kesempatan kepada siswa untuk bekerjasama dengan siswa lain, 2) siswa dapat menguasai pelajaran yang disampaikan, 3) setiap anggota dapat menjadi ahli dalam kelompok, 4) dalam proses belajar mengajar siswa saling ketergantungan positif, 5) setiap siswa dapat saling mengisi satu sama lain. Terdapat beberapa penelitian yang telah menerapkan model pembelajaran jigsaw dalam pembelajaran matematika diantaranya penelitian Purwanti (2013) pada siswa kelas XI IPS SMAN 3 Bantul materi fungsi komposisi dan fungsi invers dan Rejeki (2009) pada siswa kelas VIII G Semester 2 SMP Negeri 2 Toroh Grobogan. Hasil keduanya menyimpulkan bahwa dengan penerapan model kooperatif tipe jigsaw dapat meningkatkan hasil belajar matematika.

Meski model pembelajaran Jigsaw memberikan dampak positif, namun perlu diperhatikan juga kekurangan dari model pembelajaran ini. Soejadi (Isjoni, 2013: 55) menyatakan bahwa jumlah anggota dalam satu kelompok apabila makin besar dapat mengakibatkan makin kurang efektif kerjasama antara para anggotanya. Adapun Ibrahim, dkk (Rochman dan Majid, 2014: 222) menyatakan bahwa pembelajaran kooperatif tipe jigsaw juga membutuhkan waktu yang lama dan siswa yang pandai cenderung tidak mau disatukan dengan temannya yang kurang pandai, begitu sebaliknya.

Selain jigsaw, tipe model pembelajaran kooperatif yang juga memberikan kesempatan siswa untuk saling berbagi informasi antar siswa adalah TSTS. Teknik belajar mengajar TSTS atau dua tinggal dua tamu dikembangkan oleh Spencer Kagan tahun 1992 (Huda, 2011:140). Menurut Huda (2011), model 
pembelajaran kooperatif dengan teknik TSTS dapat memungkinkan setiap kelompok untuk saling berbagi informasi dengan kelompokkelompok lainnya. Proses pembelajaran dengan teknik TSTS secara sadar atau tidak, siswa dapat terlibat aktif dan memunculkan semangat dalam belajar. Karakteristik model pembelajaran TSTS menurut Herawati (2015) adalah adanya kerjasama siswa dalam kelompok dalam menuntaskan materi belajar, pembentukan kelompok secara heterogen, dimana anggotanya berasal dari beda ras, suku, jenis kelamin dan juga kemampuan. Selain itu, penghargaan TSTS lebih berorientasi pada kelompok daripada individu.

Langkah-langkah pembelajaran TSTS menurut Lie (2002:62) adalah 1) siswa bekerjasama dalam kelompok seperti biasa, 2) setelah selesai, dua orang dari tiap kelompok akan meninggalkan kelompoknya dan masingmasing bertamu ke kelompok yang lain, 3) dua orang yang tinggal dalam kelompok bertugas membagikan hasil kerja dan informasi ke tamu, 4) tamu meminta izin dan kembali ke kelompok mereka sendiri dan melaporkan temuannya dari kelompok lain, 5) kelompok mencocokan dan membahas hasil-hasil kerja mereka.

Kelebihan model pembelajaran TSTS diantaranya mengarahkan siswa untuk aktif, baik dalam diskusi, tanya jawab, mencari jawaban, menjelaskan dan juga menyimak materi yang dijelaskan oleh teman. Selain itu, adanya pembagian kelompok TSTS yang jelas pada tiap anggota kelompok, memungkinkan siswa untuk dapat bekerjasama dengan teman lain serta dapat mengatasi siswa yang ramai dan sulit diatur pada saat proses pembelajaran (Herawati, 2015).

Terdapat penelitian yang telah menerapkan model pembelajaran TSTS diantaranya penelitian Lapohea (2014) pada siswa kelas X SMA Negeri 1 Sindue materi logika matematika dan Herawati (2015) pada siswa kelas VI SD Negeri 53 Banda Aceh materi keliling dan luas lingkaran. Hasil keduanya menyimpulkan bahwa penerapan model pembelajaran kooperatif tipe TSTS dapat meningkatkan hasil belajar. Penggunaan model pembelajaran TSTS melibatkan siswa secara aktif dan meningkatkan pemahaman terhadap materi.

Model pembelajaran Jigsaw dan TSTS memiliki kesamaan karakteristik, diantaranya dapat menfasilitasi siswa untuk mempelajari materi dan menjelaskan apa yang telah dipahami kepada teman yang lainnya. Kedua model ini menfasilitasi siswa untuk belajar materi dari teman yang lain. Meskipun demikian, terdapat perbedaan karakteristik dari kedua model. Dalam TSTS, tidak ada siswa sebagai yang paling ahli dikarenakan ada dua orang yang akan menjelaskan materi yang sama, sedangkan dalam Jigsaw semua siswa menempati posisi yang paling ahli untuk memberikan penjelasan suatu materi kepada teman lain. Perbedaan ini bisa berdampak positif dan bisa juga berdampak negatif. Adanya posisi sebagai ahli di Jigsaw bisa memotivasi siswa dalam belajar karena siswa merasa memiliki tanggung jawab penuh dalam menjelaskan materi yang telah didapatkan kepada teman dalam kelompok asal dan bisa juga menumbuhkan rasa percaya diri dikarenakan anggota kelompoknya belum ada yang mempelajari materi yang disampaikan. Namun, hal ini juga dapat membawa dampak negatif yaitu ketika terdapat siswa dalam kelompok yang tidak menguasai ataupun salah dalam memahami materi yang menjadi bagiannya. Hal ini bisa mengakibatkan satu anggota kelompok memiliki pemahaman yang salah atau tidak memahami satu materi. Namun bisa saja tidak terjadi kesalahan dalam satu kelompok karena adanya teman lain dengan kemampuan lebih yang mempelajari sendiri dan menjelaskan kekelompoknya. Namun hal ini, berdampak hilangnya posisi ahli seseorang di kelompoknya.

Berbeda dengan Jigsaw, pada TSTS terdapat sepasang (2-3 orang) yang akan menjelaskan materi kepada kelompok lain. Adanya dua orang di TSTS , apabila salah satu tidak dapat menjelaskan maka bisa dibantu dengan pasangannya. Namun, hal ini justru menunjukkan masih adanya peluang siswa untuk bergantung pada siswa dalam proses pemberian informasi pada kelompok lain.

Terdapat penelitian yang telah membandingkan penerapan model Jigsaw dan TSTS diantaranya penelitian Singga (2011) terhadap siswa kelas IX SMP Negeri 9 Kendari pada materi SMP kelas XI semester ganjil. Hasil peneliti menyimpulkan bahwa Model pembelajaran tipe Jigsaw dan tipe TSTS secara bersama-sama mempunyai pengaruh yang signifikan terhadap hasil belajar matematika secara univarian. Selain itu, adapula penelitian Fajarudin (2015) pada siswa kelas VIII MTsN Kunir pokok bahasan bangun ruang kubus dan balok. Penelitian ini menyimpulkan bahwa 
hasil belajar matematika dengan menggunakan model pembelajaran kooperatif tipe TSTS lebih baik dibandingkan dengan hasil belajar matematika dengan model pembelajaran kooperatif tipe jigsaw.

Penelitian ini akan dilakukan dalam pembelajaran matematika pada sekolah yang telah terbiasa menerapkan cooperative learning. Selain itu, juga diterapkan pada kelas dengan siswa-siswa yang dimungkinkan untuk menguasai materi secara mandiri. Salah satu sekolah yang memenuhi kriteria tersebut adalah SMA N 1 Ambarawa.

Tujuan dilaksanakannya penelitian ini adalah untuk mengetahui ada atau tidaknya perbedaaan hasil belajar matematika antara penerapan model kooperatif tipe Jigsaw dan TSTS (Two Stay Two Stray) pada siswa kelas XI SMAN 1 Ambarawa. Diharapkan penelitian ini dapat memberi informasi dan gambaran tentang penerapan model pembelajaran kooperatif tipe Jigsaw dan TSTS dalam materi turunan fungsi aljabar, sehingga hal ini diharapkan dapat menginspirasi guru dalam memilih model pembelajaran guna meningkatkan kualitas pembelajaran. Selain itu, melalui penelitian ini diharapkan dapat memberikan kesempatan siswa untuk lebih aktif terlibat dalam pembelajaran.

\section{Metode Penelitian}

Penelitian eksperimen semu (quasi eksperimental research) ini dilaksanakan di SMA Negeri 1 Ambarawa yang beralamat di Jalan Yos Sudarso No. 46 Kupang Lor Kecamatan Ambarawa Kabupaten Semarang pada semester Genap Tahun Pelajaran 2017/2018 mulai bulan Januari sampai bulan Mei 2018. Populasi penelitian ini adalah seluruh siswa kelas XI SMA Negeri 1 Ambarawa yang berjumlah 325 siswa yang terbagi menjadi 10 kelas. Teknik pengambilan sampel dilakukan dengan cluster random sampling dimana populasi dalam penelitian dikelompokkkan menjadi sepuluh cluster sesuai kelas masing-masing yaitu XI MIPA terdiri dari 5 kelas, XI Sosial terdiri dari 4 kelas dan satu kelas XI Bahasa. Dari sepuluh kelas tersebut diclusterkan lagi menjadi jurusan MIPA 1, Sosial dan BAHASA dan terpilih jurusan MIPA. Dari lima kelas MIPA dipilih secara acak 2 kelas dan diperoleh kelas XI MIPA 1 (34 siswa) sebagai kelas eksperimen yang dikenakan pembelajaran dengan model jigsaw dan kelas XI IPA 2 (33 siswa) sebagai kelas pembanding yaitu kelas yang diberi perlakuan berupa pembelajaran dengan model TSTS.

Desain penelitian yang digunakan adalah the randomized control group pretest-posttest design, karena penelitian ini selain membandingkan kemampuan akhir juga menguji keseimbangan kemampuan awal dari kedua kelompok sampel sebelum diberi perbedaan perlakuan model pembelajaran Jigsaw dan TSTS. Perbedaan Perlakuan pembelajaran kooperatif tipe Jigsaw dan TSTS diberikan selama 5 kali pertemuan yang masing-masing terdiri dari 2 jam pelajaran (@45 menit).

Teknik pengumpulan data menggunakan metode dokumentasi untuk memperoleh data nilai ulangan yang akan dijadikan sebagai nilai pretest, metode observasi untuk menilai sejauh mana pelaksanaan model pembelajaran tipe Jigsaw dan TSTS (Two Stay Two Stray) di dalam kelas, serta metode tes untuk memperoleh data hasil belajar matematika siswa setelah diberi perlakuan(posttest). Instrumen penelitian ini yaitu tes yang terdiri dari 13 soal uraian dan lembar observasi guru. Kisi-kisi instrumen tes kemampuan akhir siswa dapat dilihat pada Tabel 1. Validasi isi istrumen tes oleh guru pendidikan matematika menyimpulkan bahwa instrumen layak digunakan untuk mengetahui hasil belajar siswa.

Uji analisis data terbagi menjadi 2 yaitu uji keseimbangan kemampuan awal dan uji hipotesis. Kedua uji menggunakan uji beda rerata untuk dua kelompok sampel yang independen. Sebelumnya dilakukan uji normalitas dengan Kolmogorov-Smirnov untuk menentukan uji beda rerata yang akan digunakan (Parametrik/ non-parametrik). Jika uji normalitas tidak terpenuhi, maka digunakan uji beda rerata dengan uji Mann-Whitney, sedangkan terpenuhi maka menggunakan Uji beda rerata Independent Sample T-Test. Terdapat dua uji Independent Sample T-Test yaitu Equal Variances Assumed dan Equal Variances not Assumed, oleh karena perlu dilakukan uji homogenitas. Jika uji homogenitas menyimpulkan bahwa kedua kelompok sampel berasal dari populasi yang memiliki variansi sama maka Independent Sample T-Test yang digunakan adalah Equal Variances Assumed, namun jika tidak terpenuhi maka menggunakan uji Equal Variances not Assumed. 
Tabel 1. Kisi-Kisi Instrumen Tes

\begin{tabular}{|c|c|c|c|}
\hline No & Indikator Soal & $\begin{array}{c}\text { Tingkat } \\
\text { Kesukaran }\end{array}$ & $\begin{array}{c}\text { Nomor } \\
\text { Soal }\end{array}$ \\
\hline 1 & $\begin{array}{l}\text { Diberikan sebuah } \\
\text { fungsi aljabar, siswa } \\
\text { dapat menentukan } \\
\text { turunan pertama dari } \\
\text { fungsi tersebut. }\end{array}$ & Mudah & $1(a-c)$ \\
\hline 2 & $\begin{array}{l}\text { Diberikan } \\
\text { kurva dan titik yang } \\
\text { menyinggung, siswa } \\
\text { menentukan gradien } \\
\text { dan persamaan garis } \\
\text { singgungnya. }\end{array}$ & Sedang & $2(a, b)$ \\
\hline 3 & 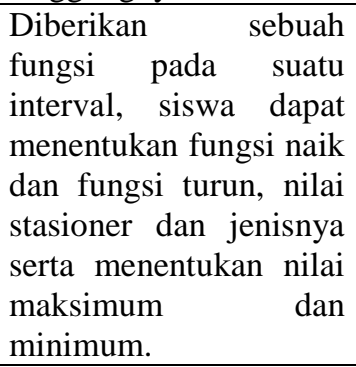 & Sedang & $3(a-c)$ \\
\hline 4 & $\begin{array}{l}\text { Diberikan } r \text { sebuah } \\
\text { fungsi waktu, siswa } \\
\text { dapat menentukan } \\
\text { rumus kecepatan dan } \\
\text { percepatan } t \text { detik, } \\
\text { percepatan pada saat } t \\
\text { diketahui, percepatan } \\
\text { saat kecepatan nol, } \\
\text { serta menentukan } \\
\text { waktu }(t) \text { agar } \\
\text { percepatannya nol }\end{array}$ & Sedang & $4(a-d)$ \\
\hline 5 & $\begin{array}{lr}\text { Diberikan } & \begin{array}{r}\text { sebuah } \\
\text { masalah }\end{array} \\
\text { turunan, } & \text { aplikasi } \\
\text { penentuan } & \text { yaitu } \\
\text { maksimum } & \text { luas } \\
\text { diketahui keliling } & \text { jika } \\
\text { dari }\end{array}$ & Sulit & 5 \\
\hline
\end{tabular}

Hasil Penelitian dan Pembahasan

Analisis Deskriptif Data Sampel Sebelum Pemberian Perlakuan

Data Kondisi awal diperoleh dari nilai ulangan harian matematika siswa SMA Negeri 1 Ambarawa. Data perolehan kemampuan awal untuk setiap kelas sampel dapat dilihat pada Tabel 2. Hasil analisis data kemampuan awal di eksperimen yang terdiri dari 34 siswa menunjukkan bahwa meski pencapaian nilai maksimum kelas eksperimen dan pembanding sama (91), namun pencapaian nilai kelas eksperimen di minimum (80), rata - rata $(86,59)$, dan standar deviasi $(3,066)$ lebih baik dibanding kelas pembanding. Hasil pretest dibagi dalam 3 kategori yaitu tinggi, sedang, dan rendah. Pengkategorian kemampuan awal dan diagram pengkategorian dapat dilihat pada Tabel 3 dan Gambar 1.

Tabel 2. Data Kemampuan Awal

\begin{tabular}{lcrrrr}
\hline & $\mathrm{N}$ & Min & Max & Mean & $\begin{array}{c}\text { Std. } \\
\text { Deviation }\end{array}$ \\
\hline Eksperimen & 34 & 80 & 91 & 86,59 & 3,066 \\
Pembanding & 33 & 76 & 91 & 85,09 & 5,064 \\
Valid N & 33 & & & & \\
(listwise) & & & & & \\
\hline
\end{tabular}

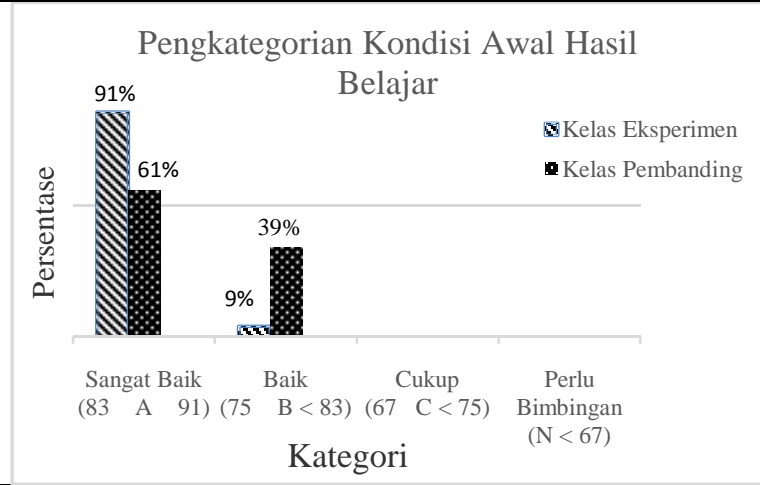

Gambar 1. Pengkategorian Kondisi Awal Hasil Belajar

\section{Analisis Inferensial Data Kemampuan Awal}

Penelitian ini menggunakan data sampel, sehingga untuk membuat simpulan pada populasi perlu dilakukan uji statistika. Sampel berjumlah 34 dan 33 siswa sehingga uji normalitas yang digunakan adalah uji Kolmogorov-Smirnov. Hasil uji normalitas dapat dilihat pada Tabel 4.

Tabel 4. Uji Normalitas Kemampuan Awal

\begin{tabular}{llrcc}
\hline & & \multicolumn{3}{c}{$\begin{array}{c}\text { Kolmogorov- } \\
\text { Smirnov }\end{array}$} \\
\cline { 3 - 5 } & Kode_Nilai_Awal & Statistic & df & Sig. \\
\hline \multirow{2}{*}{ N_Awal } & Eksperimen &, 148 & 34 &, 057 \\
& Pembanding &, 232 & 33 &, 000 \\
\hline
\end{tabular}

Tabel 4 menunjukkan bahwa uji normalitas untuk kelas eksperimen memiliki signifikan 0,057 dan signifikan kelas pembanding ,000 artinya mendekati nol yang kurang dari 0.05. sehingga dapat disimpukan bahwa nilai dari kelompok pembanding tidak berasal dari populasi yang berdistribusi normal sehingga uji beda rerata yang digunakan uji Mann-Whitney.

http://jurnal.unimus.ac.id/index.php/JPMat/index 
Hasil Uji Mann-Whitney dapat dilihat pada Tabel 5.

Tabel 5. Hasil Uji Mann-Whitney

\begin{tabular}{lr} 
Mann-Whitney U & N_Awal_ \\
Wilcoxon W & 500,500 \\
Z & 1061,500 \\
Asymp. Sig. (2-tailed) &,- 768 \\
\hline a. Grouping Variable: Kode_N_Awal &, 443 \\
\hline
\end{tabular}

Tabel 5 menunjukkan nilai signifikan sebesar 0,443 (lebih dari 0,05) yang berarti tidak terdapat perbedaan rerata yang signifikan antara kelas eksperimen dan pembanding. Hal ini berarti kondisi awal kedua kelas memiliki kemampuan awal yang seimbang.

\section{Pelaksanaan Model Pembelajaran Kooperatif Tipe Jigsaw dan TSTS}

Pelaksanaan pembelajaran dengan model pembelajaran kooperatif tipe Jigsaw maupun TSTS dilaksanakan selama 5 kali pertemuan dengan total 10 jam pelajaran. Pembelajaran dalam penelitian ini mengambil materi turunan fungsi aljabar. Pertemuan pertama, membahas konsep turunan dan aturan-aturan turunan fungsi. Pertemuan kedua, membahas gradien dan persamaan garis singgung kurva. Pertemuan ketiga, membahas tentang Aplikasi Turunan (kemonotonan, tititk ekstrim kurva fungsi, nilai maksimum dan minimum. Pertemuan keempat, tentang Perhitungan percepatan dan kecepatan serta penerapan masalah maksimum-minimum dan tentang Perhitungan percepatan dan kecepatan serta penerapan masalah maksimum-minimum.
Adapun pertemuan kelima, digunakan sebagai post-test.

Pada pertemuan pertama, pemberian konsep turunan menggunakan media power point dan aplikasi geogebra. Selanjutnya, guru membagikan Lembar Kerja 1 yaitu tentang aturan-aturan turunan fungsi yang terdiri dari 4 kode dengan materi yang berbeda. Kode 1 untuk aturan suatu konstanta dikalikan dengan suatu fungsi, kode 2 untuk penjumlahan dan pengurangan, kode 3 untuk perkalian dua fungsi, dan kode 4 untuk pembagian. Untuk pertemuan selanjutnya juga menggunakan Lembar kerja 2 tentang gradien dan persamaan garis singgung kurva, lembar kerja 3 tentang Aplikasi Turunan (kemonotonan, tititk ekstrim kurva fungsi, nilai maksimum dan minimum dan lembar kerja 4 tentang Perhitungan percepatan dan kecepatan serta penerapan masalah maksimum-minimum dan tentang Perhitungan percepatan dan kecepatan serta penerapan masalah maksimum-minimum. Masing-masing LK terdiri dari 4 kode dengan materi berbeda. Dengan lembar kerja yang sama, namun pada jigsaw untuk setiap tipe diberikan dikelompok ahli. Sedemikian sehingga setiap kelompok asal mendapatkan lembar kerja 1 dengan kode 1 sampai 4. Sedangkan diTSTS untuk setiap kode pada lembar kerja 1 dibagikan dalam kelompok asal yang berbeda, sehingga dalam kelompok asal membahas materi yang sama. Contoh Lembar kerja dengan 4 kode dapat dilihat pada Gambar 2.

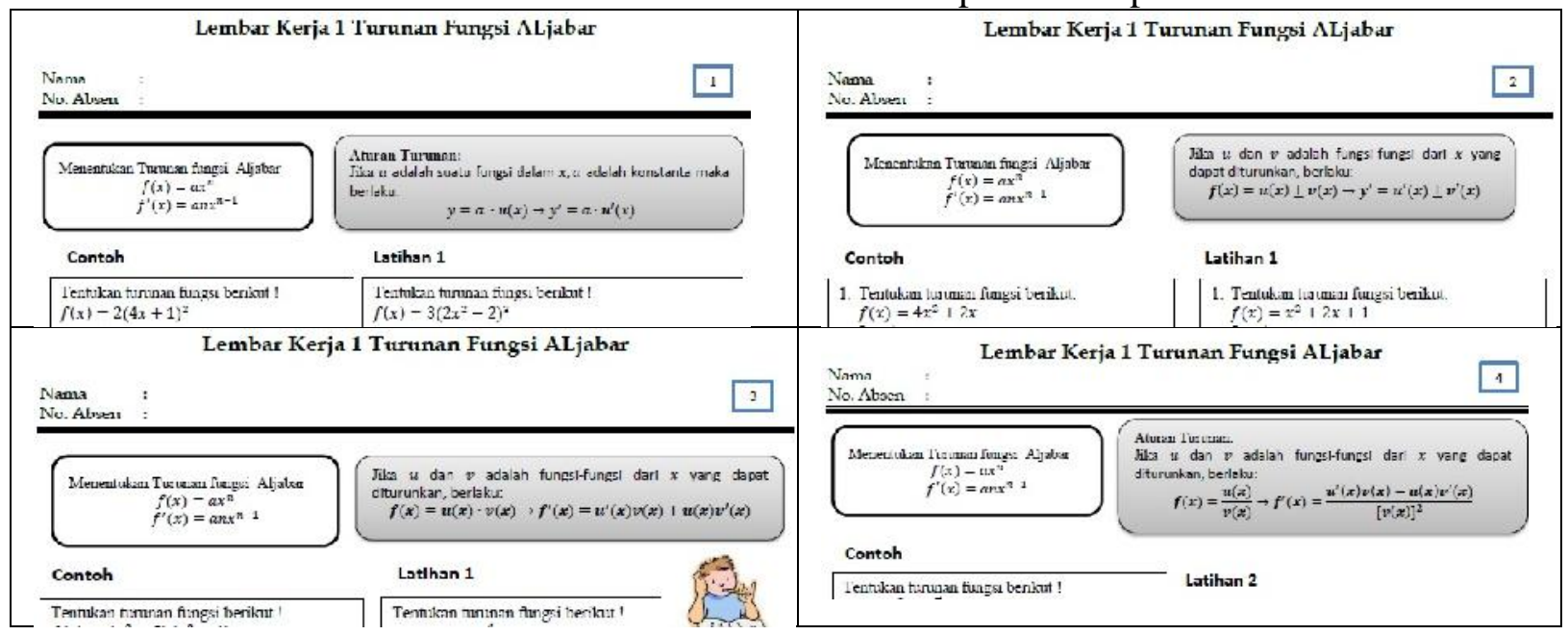

Gambar 2. Contoh LK dengan 4 Kode 
Pembagian kelompok baik pada model pembelajaran tipe jigsaw ataupun TSTS dilakukan secara heterogen dengan memperhatikan peringkat siswa berdasarkan hasil ulangan matematika. Pada Jigsaw, peringkat 1-10 disebar menjadi 8 kelompok asal, karena terdapat banyak siswa yang memiliki nilai sama mengakibatkan terdapat beberapa peringkat yang sama. Sedangkan diTSTS, peringkat 1-8 disebar menjadi 8 kelompok berbeda yaitu kelompok I ke kelompok VIII dan peringkat 9-16 juga disebar pada 8 kelompok berbeda tersebut secara acak. Siswa dengan peringkat ini yang diharapkan dapat menjadi leader dari pasangannya. Pembentukan kelompok seperti ini tidak hanya seimbang untuk setiap kelompok namun juga untuk setiap pasangan tamu maupun tuan rumah. Pembagian kelompok asal jigsaw dan TSTS dapat dilihat pada Tabel 6 dan Tabel 7 .

Tabel 6. Pembagian Kelompok Jigsaw secara Heterogen berdasarkan peringkat

\begin{tabular}{|c|c|c|c|}
\hline I & II & III & IV \\
\hline 30 & $16 / 1$ & 2 & 16 \\
\hline $2 / 12$ & 30 & 16 & 2 \\
\hline 19 & 12 & 29 & 12 \\
\hline 2 & 2 & 19 & 27 \\
\hline V & VI & VII & VIII \\
\hline 27 & 10 & 15 & 19 \\
\hline 12 & 26 & 10 & 19 \\
\hline 2 & 19 & 25 & 2 \\
\hline 2 & 12 & 19 & 19 \\
\hline
\end{tabular}

Tabel 7. Pembagian Kelompok TSTS secara Heterogen berdasarkan peringkat

\begin{tabular}{|c|c|c|c|}
\hline I & II & III & IV \\
\hline 1 & 11 & 3 & 13 \\
\hline $32 / 33$ & 23 & 30 & 19 \\
\hline 12 & 2 & 14 & 4 \\
\hline 21 & 31 & 17 & 29 \\
\hline V & VI & VII & VIII \\
\hline 5 & 15 & 7 & 9 \\
\hline 28 & 18 & 26 & 22 \\
\hline 16 & 6 & 10 & 8 \\
\hline 20 & 27 & 24 & 25 \\
\hline
\end{tabular}

Baik dijigsaw maupun TSTS diawal pembelajaran guru pasti melakukan beberapa hal diantaranya guru mengucapkan salam, berdoa, melakukan presensi, memberikan apersepsi dan moti vasi kepada siswa serta pemberian acuan. Langkah awal pembelajaran itu berlangsung dari pertemuan satu sampai empat, perbedaannya terletak pada tahap inti pembelajaran.

Kegiatan inti pada jigsaw terdiri dari tiga tahap yaitu pembagian kelompok asal, pembagian kelompok ahli, dan diskusi kelompok asal. Pembagian kelompok asal sesuai pada tabel 7. Selanjutnya, guru membagikan lembar kerja kepada siswa dan meminta mempelajari lembar kerjanya selama 5 menit. Pada tahap pembagian kelompok setiap anggota kelompok membentuk kelompok ahli sesuai pembagian yang telah ditentukan oleh guru. Kegiatan yang dilakukan dalam kelompok ahli adalah mendiskusikan materi masingmasing dan mengerjakan soal latihan 1 dan soal latihan 2 yang ada dalam lembar kerja. Setelah kegiatan diskusi dalam kelompok ahli dilakukan maka selanjutnya masuk dalam tahap diskusi kelompok asal. Guru mempersilakan setiap anggota menjelaskan ke anggota kelompoknya mengenai pembahasan materi yang didapat pada kelompok ahli, dilanjutkan dengan mengerjakan latihan soal 2 dan ayo mencoba bersama milih temannya. Sedangkan di TSTS, terdapat 3 tahap yaitu pembagian kelompok, diskusi rumah tangga, dan rotasi. Pada pembagian kelompok sesuai dengan tabel 8. Selanjutnya, guru membagikan lembar kerja dan melakukan diskusi di kelompok asal (rumah tangga). Kelompok diarahkan untuk mengumpulkan informasi yang relevan untuk menjawab pertanyaan yang diberikan yaitu soal latihan 1 dan latihan 2. Setelah waktu selesai, guru memastikan jawaban pada setiap kelompok dan menginforrmasikan akan dimulai kegiatan rotasi. Pada kegiatan rotasi, guru meminta dua perwakilan (siswa yang duduknya membelakangi papan tulis) sebagai tamu untuk berdiri dan berkunjung ke kelompok tetangga guna bertukar informasi dan mengerjakan latihan soal yang ada pada lembar kerja. Dalam kegiatan tersebut guru memberikan waktu 10 menit untuk masing-masing proses bertamu. Setelah waktu habis guru meminta siswa berdiri dan melanjutkan kegiatan bertamu ke setiap kelompok tetangga sampai kembali lagi ke kelompok rumah tangga masing-masing.

Pada saat proses pembelajaran dengan model Jigsaw ditemukan siswa yang tidak menguasai materi yang menjadi bagiannya. Hal ini mengakibatkan satu anggota kelompok memiliki pemahaman yang salah atau tidak memahami satu materi, tetapi kelompok tidak jadi salah karena adanya teman lain dengan kemampuan lebih yang mempelajari sendiri dan 
menjelaskan kekelompoknya. Sedangkan di TSTS, terdapat siswa pada saat share dikelompok tetangga hanya bergantung pada pasangannya, serta pada saat mengerjakan latihan terdapat siswa yang hanya memindah jawaban.

Hasil belajar sangat dipengaruhi oleh pelaksanaan pembelajaran. Hasil keterlaksanaan pembelajaran guru dengan menggunakan model pembelajaran kooperatif
Jigsaw dan TSTS dapat dilihat pada Gambar 3. Hasil tersebut menunjukkan baik Jigsaw maupun TSTS sudah direncanakan sesuai dengan teori yang ada dan dilakukan sesuai dengan RPP yang telah dibuat. RPP sudah sesuai dengan sintaks pembelajaran dan prinsip RPP menurut Kurikulum 2013. Hal tersebut tampak pada hasil keterlaksanaan pembelajaranyang masuk pada kategori sangat baik.

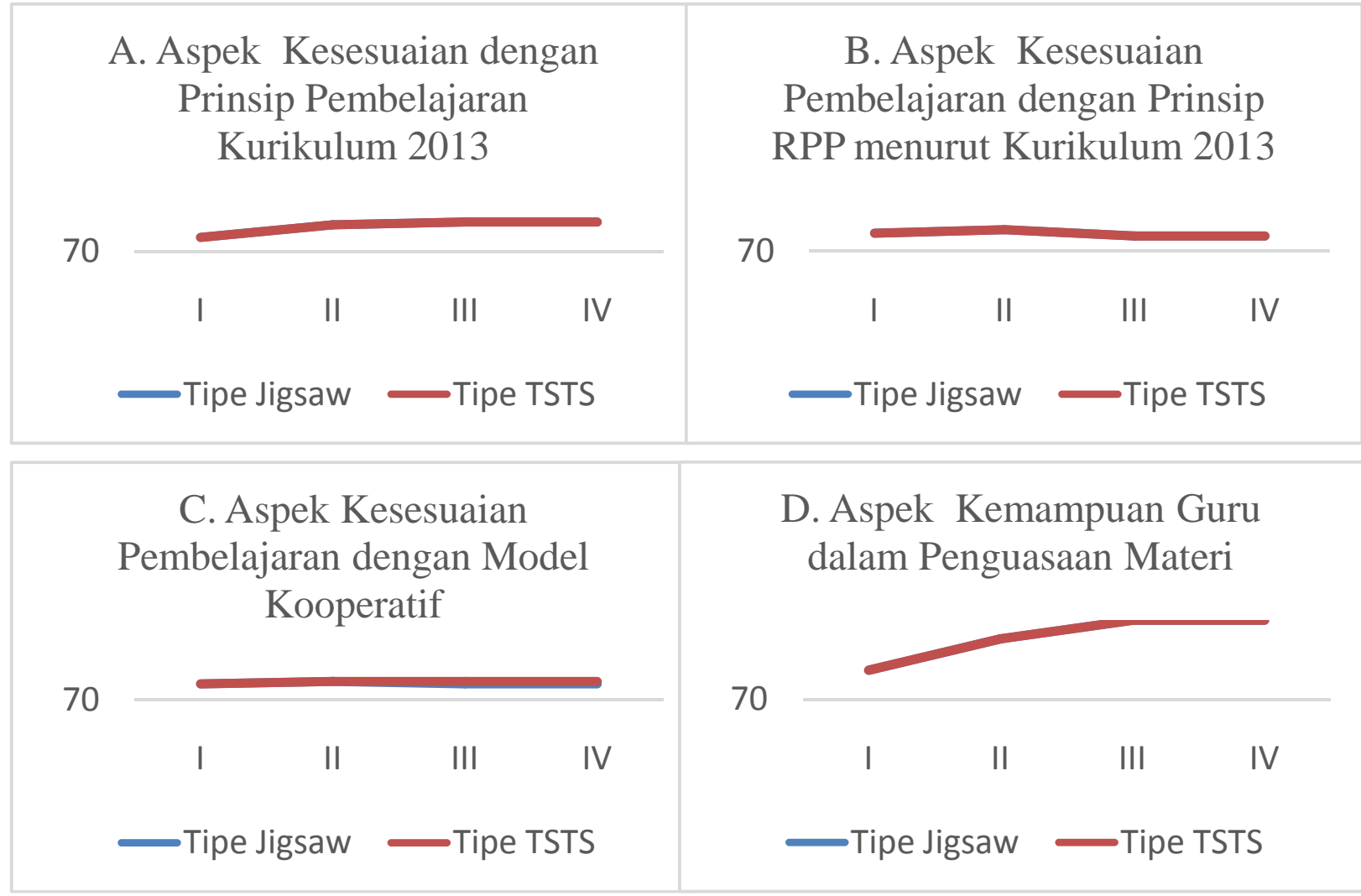

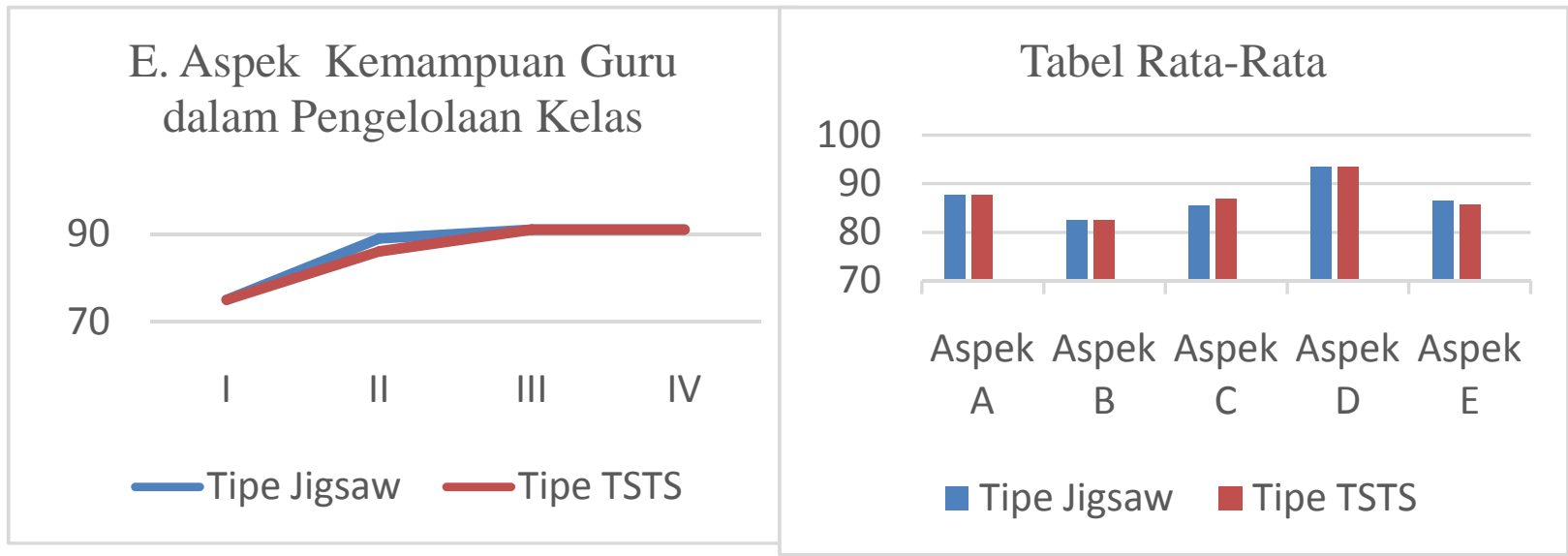

Gambar 3. Keterlaksanaan Pembelajaran dengan Model Pembelajaran Kooperatif Tipe Jigsaw dan TSTS

\section{Analisis Deskriptif Data Sampel setelah Pemberian Perlakuan}

Kondisi kemampuan akhir siswa diambil dari data posttest. Materi yang digunakan dalam post test mencakup materi Turunan fungsi aljabar dengan 5 indikator yang berbeda. Soal post test terdiri dari 13 soal uraian. Rekapitulasi hasil belajar setelah perbedaan perlakuan dapat dilihat pada Tabel 
10. Hasil analisis data kemampuan akhir dari 34 siswa pada kelas eksperimen dan 33 siswa pada kelas pembanding menunjukkan bahwa nilai tertinggi diraih oleh siswa kelas eksperimen (98), sedangkan standar deviasi kelas pembanding lebih baik dibandingkan kelas eksperimen. Seperti halnya pada data awal, hasil belajar dari kedua kelompok sampel juga dikategorikan kedalam 4 kategori dan dapat dilihat pada Gambar 2.

Tabel 10. Data Kemampuan Akhir

\begin{tabular}{lcrrrr}
\hline & $\mathrm{N}$ & \multicolumn{1}{c}{ Min } & Max & Mean & $\begin{array}{c}\text { Std. } \\
\text { Deviation }\end{array}$ \\
\hline Eksperimen & 34 & 26 & 98 & 76,81 & 15,470 \\
Pembanding & 33 & 20 & 93 & 73,79 & 12,462 \\
Valid N & 33 & & & & \\
(listwise) & & & & & \\
\hline
\end{tabular}

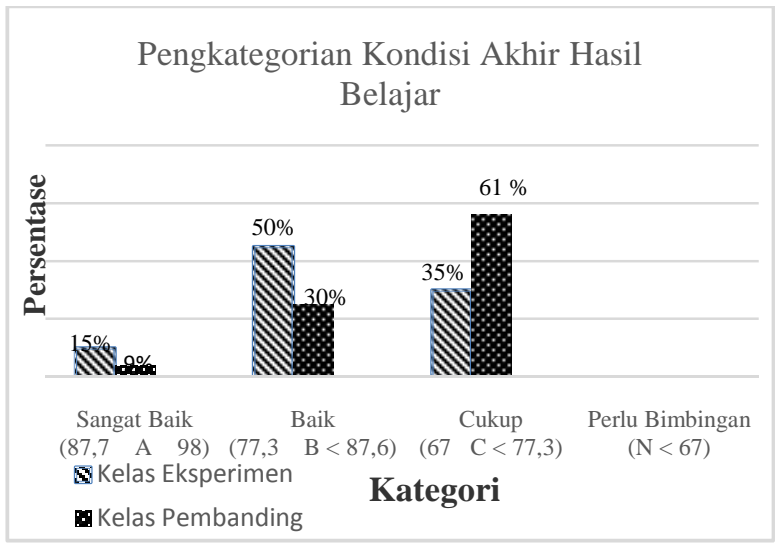

Gambar 2. Pengkategorian Kondisi Akhir Hasil Belajar

\section{Analisis Inferensial Data Kemampuan Akhir}

Uji hopotesis dilaksanakan dengan tahapan yang sama seperti pada uji keseimbangan awal. Data yang digunakan merupakan data tes tentang turunan fungsi aljabar yang diberikan setelah adanya perbedaaan perlakuan. Hasil uji normalitas dengan Kolmogorov-Smirnov dapat dilihat pada Tabel 13.

Tabel 13. Uji Normalitas Kemampuan Akhir

\begin{tabular}{llccc}
\hline & & \multicolumn{3}{c}{ Kolmogorov- $^{\text {Smirnov }^{\mathrm{a}}}$} \\
\cline { 3 - 5 } & & Statisti & \\
& Kode_Nilai_Akhir & c & df & Sig. \\
\hline N_Akhir & Eksperimen &, 260 & 34 &, 000 \\
& Pembanding &, 142 & 33 &, 090 \\
\hline
\end{tabular}

Tabel 13 menunjukkan bahwa nilai signifikan kelas eksperimen tertulis 0,000 artinya mendekati nol yang kurang dari 0,05 dan nilai signifikan kelas pembanding 0,090. Keduanya kurang dari 0,05 sehingga dapat disimpulkan bahwa kedua kelas tidak berasal dari populasi yang berdistribusi normal. Oleh karena itu, uji beda rerata yang digunakan uji Mann-Whitney. Hasil Uji Mann-Whitney dapat dilihat pada Tabel 14.

Tabel 14. Hasil Uji Mann-Whitney

\begin{tabular}{lr}
\hline & N_Akhir \\
Mann-Whitney U & 387,500 \\
Wilcoxon W & 948,500 \\
Z & $-2,178$ \\
Asymp. Sig. (2- &, 029 \\
tailed) & \\
\hline
\end{tabular}

a. Grouping Variable: Kode_Akhir

Pada tabel 14 tampak bahwa nilai Asymp. Sig(2-tailed) sebesar 0,029 (kurang dari $0,05)$ dengan rata-rata kelas eksperimen $(76,81)$ lebih tinggi dibandingkan rata-rata kelas pembanding (73,79), sehingga dapat disimpulkan bahwa penerapan jigsaw menghasilkan hasil belajar matematika yang lebih baik pada siswa kelas XI SMA N 1 Ambarawa. Hasil ini sesuai dengan dugaan awal. Terdapat faktor yang menyebabkan jisaw lebih baik yaitu kekurangan pada jigsaw dimana siswa tidak menguasai materi yang menjadi bagiannya dapat teratasi dengan adanya teman lain berkemampuan lebih yang mempelajari sendiri dan menjelaskan kepada kelompoknya. Hal ini sejalan dengan kelebihan tipe jigsaw yang diungkapkan oleh Ibrahim (Rochman dan Majid, 2014: 222) yaitu dapat memberikan kesempatan kepada siswa untuk bekerjasama dengan siswa lain dan siswa dapat saling mengisi satu sama lain. Sedangkan di TSTS, dalam proses menjelaskan terdapat siswa yang bergantung pada pasangannya dan lama waktu perpindahan untuk rotasi terlalu cepat.

\section{Simpulan dan Saran}

Simpulan

Berdasarkan hasil penelitan yang telah dilakukan dapat disimpulkan bahwa terdapat perbedaan hasil belajar matematika antara penerapan model kooperatif tipe Jigsaw dan TSTS (Two Stay Two Stray) pada siswa kelas XI SMAN 1 Ambarawa. Terlihat dari hasil uji hipotesis dengan Man-Whitney menghasil nilai signifikansi 0,029(kurag dari 0,05) dengan ratarata kelas eksperimen $(76,81)$ lebih tinggi dibandingkan rata-rata kelas pembanding $(73,79)$. Berdasarkan kedua hasil tersebut maka dapat disimpulkan bahwa penerapan jigsaw secara signifikan menghasilkan hasil belajar matematika siswa kelas XI SMAN 1 Ambarawa lebih baik dari pada penerapan TSTS . 
Saran

Penelitian ini telah menunjukkan bahwa pemilihan penerapan model pebelajaran tipe Jigsaw memberikan hasil belajar yang lebih baik sehingga disarankan bagi guru untuk dapat menerapkan model pembelajaran kooperatif tipe jigsaw. Penelitian ini menunjukkan bagaimana siswa dapat saling belajar, oleh karenanya disarankan bagi siswa dapat antusias dalam mengikuti setiap proses pembelajaran dan hendaknya dapat menyadari bahwa belajar dapat dilakukan melalui diskusi dengan temannya serta bagi peneliti lain yang akan membandingkan model pembelajaran tipe TSTS (Two Stay Two Stray) dan Jigsaw untuk menerapkan dalam materi lain pada pembelajaran matematika.

\section{Daftar Pustaka}

Christina, Sri Purwanti. (2013). Meningkatkan Hasil Belajar Matematika Materi Fungsi Komposisi dan Fungsi Invers Menggunakan Pembelajaran Model Jigsaw pada Siswa Kelas XI IPS SMA Negeri 3 Bantul. Prosiding Seminar Nasional Matematika dan Pendidikan Matematika FMIPA UNY, tanggal 9 November 2013. Yogyakarta: Universitas Negeri Yogyakarta. (Online). Diakses 11 Maret 2018. http://eprints.uny.ac.id/10741/1/P\%20\%2018.pdf.

Dwitagama, Dedi \& Kusumah, Wijaya. 2012. Mengenal Penelitian Tindakan Kelas, Edisi Kedua. Jakarta: Indeks.

Fajarudin, Fajar. (2015). Perbedaan Hasil Belajar Matematika Siswa Meggunakan Model Pembelajaran Kooperatif Two Stay Two Stray dan Jigsaw pada Kelas VIII MTsN Kunir Blitar. Skripsi, (Online). Diakses 12 Maret 2018). http://repo.iaintulungagung.ac.id/1748/.

Huda, Miftahul. (2011). Cooperative Learning: Metode, Teknik, Struktur dan Model Terapan. Yogyakarta: Pustaka Pelajar.

Herawati. (2015). "Penerapan Model Pembelajaran Two Stay Two Stray untuk Meningkatkan Prestasi Belajar Siswa pada Materi Keliling dan Luas Lingkaran di Kelas VI SD Negeri 53 Banda Aceh". Jurnal Peluang Vol. 3 No 2 April 2015. SD Negeri 53 Banda
Aceh. (Online). Diakses pada 19 Februari 2018.

Isjoni. (2013). Cooperative Learning: Mengembangkan Kemampuan Belajar Berkelompok. Bandung: Alfabeta.

La Singga. (2011)." Pengaruh Model Pembelajaran Kooperatif Jigsaw dan TSTS terhadap hasil belajar siswa." Jurnal Pendidikan Matematika Vol 2 No.1. Januari 2011. Kendari.

Lapohea, Amrina Zainab. (2014). "Penerapan Model Pembelajaran KooPERATIF Tipe Two Stay Two Stray Untuk Meningkatkan Hasil Belajar Siswa Pada Materi Logika Matematika". Jurnal Elektronik Pendidikan Matematika Tadulako Vol. 1 No. 2 Maret 2014. Sindue. (Online). Diakses pada 19 Februari 2018.

Lie, Anita. (2002). Cooperative Learning: mempraktikan cooperatve learning di ruang-ruang kelas. Jakarta: PT Grasindo.

Majid, Abdul \& Rochman, Chaerul. (2014). Pendekatan Ilmiah dalam Implementasi Kurikulum 2013. Bandung: PT Remaja Rosdakarya.

Mulyasa. (2013). Pengembangan dan Implementasi Kurikulum 2013. Bandung: PT Remaja Rosdakarya.

Ratri, Pipit Kartika. (2013). Perbedaaan Hasil Belajar Matematika Model Pembelajaran Teams Games Tournament (TGT) Menggunakan Manik-manik dengan Model Pembelajaran Teams Games Tournament (TGT) Menggunakan Boneka Garis Bilangan dalam Operasi Penjumlahan dan Pengurangan Bilangan Bulat pada Siswa Kela VI SD/MI. Skripsi. Salatiga: Universitas Kristen Satya Wacana

Rejeki, Ning Endah Sri. (2009). "Meningkatkan Hasil Belajar Matematika Melalui Model Pembelajaran Kooperatif Tipe Jigsaw pada Siswa Kelas VIII G Semester 2 SMP Negeri 2 Toroh Grobogan”. Jurnal Lemlit Vol. 3 No. 2 Desember 2009. Grobogan.

Rusman. (2013). Model-model pembelajaran: Mengembangkan Profesionalisme Guru.Edisi kedua. Jakarta:Rajawali Pers. 
Suprijono, Agus. (2009). Cooperative Learning: Teori dan Aplikasi PAIKEM. Yogyakarta: Pustaka Pelajar.

Sudjana, Nana. (2005). Penilaian Hasil Proses Belajar Mengajar. Bandung: PT Remaja Rosdakarya.

Slavin, Robert E. (2005). Cooperative Learning: Teori, Riset dan Praktik. Bandung: Nusa Media.

Sulistyaningsih, Dwi \& Joko, Iswahyudi. (2012). Meningkatkan Hasil Belajar Matematika Siswa Melalui Metode Pembelajaran Jigsaw Berbantu CD Pembelajaran Materi Eksponen Kelas $X$. Seminar Hasil-Hasil Penelitian LPPM UNIMUS. Semarang, 2012: Universitas Muhammadiyah

Semarang.(Online). Diakses pada 18 April 2018. http://jurnal.unimus.ac.id/index.php/psn 12012010/article/viewFile/526/575.

Sugiyono. (2014). Metode Penelitian Pendidikan (Pendekatan Kuantitatif,
Kualitatif, dan $R \& D)$. Bandung:Alfabeta.

Sukmadinata, Nana Syaodih. (2012). Metode Penelitian Pendidikan. Bandung: PT Remaja Rosdakarya.

Tampubolon, Saur. (2014). Penelitian Tindakan Kelas Sebagai Pengembangan Profesi Pendidik dan Keilmuan. Jakarta: Erlangga.

Taniredja, Tukiran dkk. (2010). Model-model Pembelajaran Inovatif. Bandung: Alfabeta

Utomo, Dedi Setyo. (2013). Perbedaan Belajar Siswa Menggunakan Model Pembelajaran Tutor Sebaya dan Mekanistik pada Materi Bangun Ruang Sisi Datar di SMP Pangudi Luhur Salatiga Kelas VIII Tahun Ajaran 2012/2013. Skripsi. Salatiga: Universitas Kristen Satya Wacana

Purwanto, Ngalim. (1990). Psikologi Pendidikan. Bandung:PT Remaja Rosdakarya 